\title{
Evaluation of nitrogen metabolites as indices of nitrogen utilization in sheep given frozen and dry mature herbages
}

\author{
A. R. EGAN AND R. C. KELLAWAY* \\ Department of Agronomy, Waite Agricultural Research Institute, \\ Private Bag I, Glen Osmond, South Australia
}

(Received 6 fuly 1970-Accepted 18 March 1971)

\begin{abstract}
I. Twenty herbages at different stages of maturity containing from 0.77 to $5.23 \mathrm{~g}$ nitrogen/ $100 \mathrm{~g}$ organic matter were harvested, and green herbages were rapidly frozen and stored at $-\mathrm{I} 5^{\circ}$. Each herbage was offered at levels approximating to ad lib. to a group of three sheep, individually penned. Intake, digestion and retention of $\mathrm{N}$ were studied during a ro $\mathrm{d}$ collection period after a $9 \mathrm{~d}$ preliminary period.

2. General regressions relating apparently digested $N(N A, g / d)$, urinary $N$ excretion (UN, g/d) and retention of $\mathrm{N}(\mathrm{NR}, \mathrm{g} / \mathrm{d})$ to $\mathrm{N}$ intake $(\mathrm{NI}, \mathrm{g} / \mathrm{d})$ were established: $\mathrm{NA}=$ $0.88 \mathrm{NI}-3.25$ ( $\left.\pm \mathrm{I} \cdot \mathrm{I}_{4} ; \mathrm{SE}_{\mathrm{b}}= \pm 0.0 \mathrm{I}_{3}\right) ; \mathrm{UN}=2.48+0.35 \mathrm{NI}+0.0049 \mathrm{NI}^{2}\left( \pm 3.09 ; \mathrm{SE}_{\mathrm{bl}}=\right.$ $\left.\pm 0.1_{5} 6 ; \mathrm{SE}_{\mathrm{b} 2}= \pm 0.003\right) ; \mathrm{NR}=0.25 \mathrm{NI}-\mathrm{I} .92\left( \pm 2.40 ; \mathrm{SE}_{\mathrm{b}}= \pm 0.029\right)$. These equations accounted for $99 \%$ of the variability in $\mathrm{N}$ apparently digested, $86 \%$ of the variability in urinary $\mathrm{N}$ excreted, and $63 \%$ of the variability in $\mathrm{N}$ retained.

3. Concentrations of ammonia and trichloroacetic-acid-precipitable $N$ in the reticuloruminal digesta and of urea and $\alpha$-amino- $N$ in plasma were determined immediately before feeding, and at $\mathrm{I}$ and $4 \mathrm{~h}$ after feeding. Relationships between concentrations of metabolites in the reticulo-ruminal digesta and in plasma, and $\mathrm{N}$ intake, $\mathrm{N}$ apparently digested, urinary $\mathrm{N}$ output and retained $\mathrm{N}$ were examined. Estimates of urinary $\mathrm{N}$ loss and of retained $\mathrm{N}$ based upon metabolite concentrations at individual sampling times were characterized by high residual variabilities. Error terms were in some instances reduced significantly when both the basal (before feeding) metabolite concentrations and the increments in metabolite concentrations after feeding were included in the one equation. The best relationships, based on plasma urea concentrations, accounted for only $74 \%$ of variability in urinary $N$ output.

4. In multiple regressions a significant portion of the variability in urinary $N$ output and in retained $\mathrm{N}$ which was not accounted for by $\mathrm{N}$ intake could be accounted for by inclusion of metabolite values.

5. The concentration of urea in plasma was the most effective basis for prediction of $\mathrm{N}$ utilization. However, no prediction equation accounted for more than $90 \%$ of the total variability in $\mathrm{N}$ output, and no equation accounted for more than $7 \mathrm{r} \%$ of the total variability in $\mathbf{N}$ retention. The feasibility of developing techniques for examination of efficiency of $\mathbf{N}$ utilization by a particular class of animal, based upon digesta and plasma metabolite concentrations is discussed.
\end{abstract}

The efficiency of use of dietary nitrogen by ruminants is most commonly described by the total $\mathrm{N}$ retention during standardized pen-feeding experiments. In many studies on the digestion and utilization of various sources of protein and non-protein $\mathrm{N}$, the concentrations of such metabolites as ammonia in the reticulo-ruminal digesta or urea in plasma have been related to the efficiency of use of the dietary $\mathrm{N}$ (Chalmers $\&$ Synge, 1954; Lewis, I957; el-Shazly, I958; Jasiorowski, 1960). From such studies it has been stuggested that blood urea and ruminal ammonia concentrations may themselves serve as effective indices of $\mathrm{N}$ utilization. Tagari, Dror, Ascarelli \& Bondi (1964) and Abou Akkada \& Osman (1967) have reported relationships between the percentages of ingested $\mathrm{N}$ excreted in the urine, or of ingested $\mathrm{N}$ retained by the animal, and

* Present address: Department of Animal Production, University of Sydney, Sydney, NSW, Australia. 
the changes in either ruminal ammonia concentration or blood urea concentration after feeding. Such relationships could be of great value in estimating, at a particular point in time, the efficiency of use of herbage $\mathrm{N}$ by a grazing animal, where standard balance techniques are difficult to apply. However, while these and similar relationships may be strong within a restricted range of diets or under closely controlled experimental conditions, further examination over a wide range of dietary conditions is necessary before reliance can be placed upon their use for evaluation of $\mathrm{N}$ utilization in field situations.

In the experiment reported here the utilization of dietary $\mathrm{N}$ by penned sheep was examined for twenty diets, consisting of green herbages, frozen at time of harvest, or mature pasture residues. The diets were chosen to produce differences in patterns of $\mathrm{N}$ utilization, and it is not implied that the particular efficiency of $\mathrm{N}$ utilization achieved on any given diet was solely a dietary characteristic, or that the results are indices of nutritive values of the diets.

Factors such as the physiological state of the animal, the level of supply and possibly the nature of energy-yielding nutrients, and the length of time for which a particular diet is given will influence the efficiency of utilization of $\mathrm{N}$. Also the relationship between metabolite concentrations and the amount of $\mathrm{N}$ excreted in the urine or retained in the body may vary with body size and physiological state of the animal. This study was restricted to an examination of such relationships existing with young Merino wethers in a particular weight range, fed at near ad lib. levels. The relationships under investigation were those between metabolite concentration and the pattern of $\mathrm{N}$ utilization as expressed at a particular point in time, however that pattern was achieved.

Concentrations of individual $\mathrm{N}$ metabolites in digesta and plasma and the extent of their change over specified intervals of time after commencement of feeding were examined either $(a)$ as independent factors allowing direct estimation of $\mathrm{N}$ utilization or $(b)$ as factors which might improve the estimation of actual urinary $\mathrm{N}$ loss and of $\mathrm{N}$ retention, when $\mathrm{N}$ intake is known or can be estimated.

\section{EXPERIMENTAL}

\section{Animals}

Twelve Merino wethers aged between 18 months and 2 years were selected from a farm flock on the basis of uniform appearance. Their body-weights ranged between 33 and $45 \mathrm{~kg}$ during the period of the experiment. Each animal was individually housed in an outdoor pen on a concrete floor. All animals were harnessed to allow attachment of faeces collection bags and urine collectors (Allden \& Jennings, r969).

\section{Diets}

Twenty herbages containing $0 \cdot 77-5.23 \mathrm{~g} \mathrm{~N} / 100 \mathrm{~g}$ organic matter were harvested between September I966 and February 1967. The botanical and chemical compositions of the herbages are described in more detail by Kellaway (1969). Green herbages were frozen rapidly and stored at $-15^{\circ}$ and senescent herbages were stored at ambient 
temperatures. Each diet was given to a group of three animals, offered first ad lib. to determine intake levels, then at reduced levels such that orts were less than $10 \%$ of total intake. For all frozen herbages the daily ration was offered in two portions to avoid any wastage through spoiling of residues left from earlier meals.

Table I. Concentration of nitrogen in the diet, and mean values for $N$ intake and faecal and urinary $N$ output by three sheep

\begin{tabular}{|c|c|c|c|c|c|}
\hline \multicolumn{3}{|c|}{ Diet } & \multirow[b]{2}{*}{$\begin{array}{c}\mathrm{N} \\
\text { intake } \\
(\mathrm{g} / 24 \mathrm{~h})\end{array}$} & \multirow[b]{2}{*}{$\begin{array}{c}\mathrm{N} \text { in } \\
\text { faeces } \\
(\mathrm{g} / 24 \mathrm{~h})\end{array}$} & \multirow[b]{2}{*}{$\begin{array}{c}\mathrm{N} \text { in } \\
\text { urine } \\
(\mathrm{g} / 24 \mathrm{~h})\end{array}$} \\
\hline No. & Description* & $\begin{array}{l}\mathrm{N} \text { con- } \\
\text { centration } \\
\text { (\% organic } \\
\text { matter })\end{array}$ & & & \\
\hline $\mathbf{I}$ & $\begin{array}{l}\text { Wimmera ryegrass (Lolium rigi- } \\
\text { dum): subterranean clover } \\
\text { (Trifolium subterraneum) }\end{array}$ & 4.27 & $35 \cdot 2$ & $6 \cdot 1$ & - \\
\hline 2 & Wimmera ryegrass & $3 \cdot 18$ & $34^{\cdot I}$ & $7 \cdot 7$ & 一 \\
\hline 3 & Phalaris (Phalaris tuberosa) & 4.19 & $43 \cdot 5$ & $8 \cdot 2$ & - \\
\hline 4 & $\begin{array}{l}\text { Mixed grasses: subterranean } \\
\text { clover }\end{array}$ & 3.52 & $23 \cdot 1$ & $4 \cdot 8$ & 14.7 \\
\hline 5 & Wimmera ryegrass & $2 \cdot 48$ & $18 \cdot 2$ & $6 \cdot 4$ & $7 \cdot 9$ \\
\hline 6 & Lucerne (Medicago sativa) & $4 \cdot 22$ & $32 \cdot 6$ & $5 \cdot 8$ & $19 \cdot 2$ \\
\hline 7 & $\begin{array}{l}\text { Lucerne: cocksfoot (Dactylis } \\
\text { glomerata) }\end{array}$ & $3 \cdot 14$ & $28 \cdot 5$ & $7 \cdot 6$ & $16 \cdot 8$ \\
\hline 8 & Green oats (Avena sativa) & $3 \cdot 20$ & $29^{\cdot} I$ & $7 \cdot 1$ & $14 \cdot 4$ \\
\hline 9 & $\begin{array}{c}\text { Capeweed (Cryptostemma calendula): } \\
\text { barley grass (Hordeum leporinum) }\end{array}$ & $2 \cdot 05$ & $19 \cdot 0$ & $8 \cdot 1$ & - \\
\hline 10 & Green oats (lower cut of 8 ) & $2 \cdot 27$ & $14 \cdot 6$ & $3 \cdot 6$ & $6 \cdot 8$ \\
\hline II & Lucerne & $I \cdot 74$ & 13.9 & $5 \cdot 9$ & $16 \cdot 8$ \\
\hline 12 & Wimmera ryegrass & $I \cdot 7 I$ & $14 \cdot 7$ & $5 \cdot 3$ & 10.6 \\
\hline 13 & Lucerne: cocksfoot & $3 \cdot 02$ & $25 \cdot 8$ & $5 \cdot 9$ & II $\cdot 2$ \\
\hline 14 & $\begin{array}{l}\text { Lucerne: cocksfoot (lower cut } \\
\text { of } \mathrm{I}_{3} \text { ) }\end{array}$ & $2 \cdot 05$ & 13.7 & $5 \cdot 4$ & $8 \cdot 2$ \\
\hline 15 & Wimmera ryegrass & $x \cdot 46$ & $8 \cdot 0$ & $4 \cdot 3$ & $5 \cdot 4$ \\
\hline I6 & Mature wild oats (Avena fatua) & 0.77 & $2 \cdot 9$ & $2 \cdot 3$ & $2 \cdot 4$ \\
\hline 17 & $\begin{array}{l}\text { Mixed grasses: strawberry clover } \\
\text { (Trifolium fragiferum) }\end{array}$ & $4 \cdot 38$ & $38 \cdot 7$ & $8 \cdot 2$ & $23 \cdot 0$ \\
\hline I8 & Mixed grasses: strawberry clover & $5 \cdot 23$ & $40 \cdot 6$ & $7 \cdot 0$ & $26 \cdot 2$ \\
\hline 19 & $\begin{array}{l}\text { Capeweed:barley grass (mature } \\
\text { cut of 9) }\end{array}$ & $1 \cdot 68$ & $9 \cdot 2$ & $5 \cdot 9$ & $3 \cdot 7$ \\
\hline 20 & Lucerne hay (chaffed) & 4.06 & $45^{\prime 2}$ & $9 \cdot 6$ & $29 \cdot 0$ \\
\hline
\end{tabular}

\section{Design and statistical analysis}

Each diet was given to three sheep, which received, as an experimental group, four or five diets in successive periods. Each feeding period was of ig d duration, collections of faeces being made during the last ro $\mathrm{d}$ and of urine during the last $4 \mathrm{~d}$ within that period. Samples of reticulo-ruminal digesta and of venous blood were taken on the final day of each period, after the last collection of faeces and urine. For all results, differences between sheep within groups were examined by analysis of variance and differences between groups of sheep were examined by regression analysis. No significant portion of the variability not explained by the regression could be attributed to differences between groups of sheep. All regressions relating indices of 
$\mathrm{N}$ utilization were derived from individual data, using the GENSTAT (WellsbourneWaite) General Statistical Program.

\section{Analysis of feeds, faeces and urine}

Botanical composition of the feed material was determined by hand separation of samples taken during harvesting operations. Chemical analyses were made on samples taken at the time of feeding, herbage being subsampled daily and bulked, frozen, freeze-dried and ground to pass a $\mathrm{I} \cdot 0 \mathrm{~mm}$ sieve. Faeces were collected daily at 08.00 hours, and were macerated, subsampled, frozen and freeze-dried for subsequent analysis. The remaining portion of faeces was oven-dried to constant weight at $85^{\circ}$ to determine dry-matter content, and subsamples were subsequently dry-ashed at $600^{\circ}$ for determination of organic matter.

Urine was collected over 4 successive days during the collection period for all but four diets (Table $\mathrm{I})$; $\mathrm{I} \mathrm{ml}$ of preservative solution $(2 \%(\mathrm{w} / \mathrm{v})$ thymol in $\mathrm{I}: 4$ butanolwater) was added to the collection vessel daily. Urine was collected daily at 08.00 hours, or, when the volume was large, at several times during the day and night. At each collection the volume of urine was measured and 10\% was added to bulk containers for each individual sheep, and immediately frozen. The bulked urine was thawed and thoroughly mixed before subsampling for analysis.

Subsamples of feed, faeces and urine were analysed for $\mathrm{N}$ by the Kjeldahl method (McKenzie \& Wallace, 1954).

\section{Analysis of ruminal digesta and plasma}

Reticulo-ruminal digesta samples (about $200 \mathrm{ml}$ ) were drawn at $\mathrm{T}_{\mathbf{0}}$ (immediately before feeding at 08.00 hours), $T_{1}$ ( $\mathrm{r}$ after feeding) and $T_{4}(4 \mathrm{~h}$ after feeding). These times represented the situations before feeding, at the end of a period of rapid feeding, and at a time when the animals were resting after feed ingestion, and were similar to the sampling times chosen by Abou Akkada \& Osman (1967). Samples were obtained by stomach tube, precautions being taken to sample well into the digesta within the rumen and to prevent contamination from saliva. The sample was strained through a double thickness of bolting silk and immediately removed to the laboratory. Analyses for ammonia were by the microdiffusion technique (Conway, 1957) and were commenced immediately after sampling. The samples were then frozen and at a later stage analysed for the trichloroacetic acid-precipitable $\mathrm{N}$ fraction (TCA-N) by the method of Cline, Hershberger \& Bentley (1958).

Blood samples $(20 \mathrm{ml})$ were drawn from the external jugular vein into heparinized syringes at $T_{0}, T_{1}$ and $T_{4}$. Plasma was analysed for urea (Conway, 1957) and total amino acids (Fisher, Bunting \& Rosenberg, 1963).

\section{Units of measurement}

In all relationships examined the results are expressed as follows: $\mathrm{N}$ intake, $\mathrm{N}$ apparently digested, $\mathrm{N}$ excreted in faeces, $\mathrm{N}$ excreted in urine and $\mathrm{N}$ retained $(\mathrm{g} N / \mathrm{d})$, $\mathrm{N}$ concentration in the diet ( $\mathrm{g} / \mathrm{roog}$ organic matter), ruminal ammonia $\mathrm{N}$ concentration (mg $\mathrm{NH}_{3}-\mathrm{N} / 100 \mathrm{ml}$ strained digesta), TCA-N $(\mathrm{mg} \mathrm{N} / \mathrm{roO} \mathrm{ml}$ strained 
digesta), plasma urea $\mathrm{N}$ (mg urea $\mathrm{N} / \mathrm{roo} \mathrm{ml}$ plasma), plasma amino acids (mg $\alpha$-amino$\mathrm{N} / \mathrm{roo} \mathrm{ml}$ plasma).

The relative strengths of the relationships between the variables are indicated in the tables of results by the statistic $r^{2}$, denoting the proportion of the total variability in the dependent variable which is accounted for by fitting the independent variable. In general, relationships giving values less than $20 \%$ are not shown in the tables. Regression equations given were tested for significance by analysis of variance, and standard deviations are presented as guides to the value of each equation for prediction purposes. The standard error of the slope of the regression line $\left(\mathrm{SE}_{\mathrm{b}}\right)$ is also given.

\section{RESULTS AND DISCUSSION}

\section{General relationships among $N$ intake, $N$ apparently digested, faecal $N$ output, urinary $N$ output and $N$ retained}

The general relationships between $\mathrm{N}$ intake (NI), $\mathrm{N}$ apparently digested (NA), urinary $\mathrm{N}$ output (UN) and retention of $\mathrm{N}(\mathrm{NR})$ observed for the twenty diets are shown in Fig. I. The apparent digestibility of $\mathrm{N}$ increased with $\mathrm{N}$ intake:

$$
\mathrm{N} \text { digestibility } \%=40 \cdot \mathrm{I}+\mathrm{I} \cdot \mathrm{INI} \pm \mathrm{II} \cdot \mathrm{I}\left(r^{2}=0.63 ; \mathrm{SE}_{\mathrm{b}}= \pm 0 \cdot \mathrm{I}_{3}\right)
$$

Though the relationships between $\mathrm{N}$ intake and faecal $\mathrm{N}(\mathrm{FN})$ output were not strong $\left(r^{2}=0.64\right)$, about $99 \%$ of the variability in $\mathrm{N}$ apparently digested was accounted for by variability in the $\mathrm{N}$ intake, the relationship being described by the equation

$$
\mathrm{NA}=0.88 \mathrm{NI}-3.25 \pm \mathrm{I} \cdot 14 \quad\left(r^{2}=0.99 ; \mathrm{SE}_{\mathrm{b}}= \pm 0.0 \mathrm{I}_{3}\right) .
$$

Losses of $\mathrm{N}$ in urine increased with intake of $\mathrm{N}$, the best single relationship being curvilinear. Approximately $86 \%$ of the variability in urinary $\mathrm{N}$ excretion was accounted for by variability in $\mathrm{N}$ intake:

$$
\begin{gathered}
\mathrm{UN}=2 \cdot 48+0.35 \mathrm{NI}+0.0049 \mathrm{NI}^{2} \pm 3.09\left(r^{2}=0.86\right) \quad\left(\mathrm{SE}_{\mathrm{b} 1}= \pm 0.156 ;\right. \\
\left.\mathrm{SE}_{\mathrm{b} 2}= \pm 0.003\right) .
\end{gathered}
$$

$\mathrm{N}$ retained may be predicted from the two regression equations 2 and 3 (NA-UN) to reach zero at an $\mathrm{N}$ intake of approximately $12 \mathrm{~g} / \mathrm{d}$ (Fig. $\mathrm{I}$ ). From these equations, a maximum $\mathrm{N}$ retention of $+8.2 \mathrm{~g} \mathrm{~N} / \mathrm{d}$ would be achieved at an intake of $54 \mathrm{~g} \mathrm{~N} / \mathrm{d}$ (outside the range of our observations), though the amount of $\mathrm{N}$ retained increased little when intakes exceeded $35 \mathrm{~g} \mathrm{~N} / \mathrm{d}$. A simple regression of $\mathrm{N}$ retention upon $\mathrm{N}$ intake showed a significant linear relationship:

$$
\mathrm{NR}=0.25 \mathrm{NI}-\mathrm{x} \cdot 92 \pm 2 \cdot 40 \quad\left(r^{2}=0.63 ; \mathrm{SE}_{\mathrm{b}}= \pm 0.029\right),
$$

which predicted $\mathrm{N}$ retained to reach zero when $\mathrm{N}$ intake was about $7 \cdot 8 \mathrm{~g} / \mathrm{d}$. From this equation $\mathrm{N}$ retention was predicted to increase indefinitely with increasing $\mathrm{N}$ intake, and gave estimates of $\mathrm{N}$ retention which exceeded those calculated by the twoequation method at intakes below $23 \mathrm{~g} \mathrm{~N} / \mathrm{d}$ and above $35 \mathrm{~g} \mathrm{~N} / \mathrm{d}$.

Neither equation for estimation of $\mathrm{N}$ retention from $\mathrm{N}$ intake accounted for more than $65 \%$ of the variability in $\mathrm{N}$ retained. Animals had entered positive $\mathrm{N}$ balance at intakes as low as $\log \mathrm{g} / \mathrm{d}$ on some diets, while in other instances they were in 
negative $\mathrm{N}$ balance at intakes of $\mathrm{I} 5 \mathrm{~g} \mathrm{~N} / \mathrm{d}$. Hence much of the variability in $\mathrm{N}$ retained could not be accounted for by differences in $\mathrm{N}$ intake. It is recognized that the efficiency of utilization of dietary $\mathrm{N}$ is greatly dependent on solubility of the dietary $\mathrm{N}$ components (McDonald, 1952; Chalmers \& Synge, 1954) and the amount of readily fermentable carbohydrate (Tagari et al. 1964; Robertson \& Hawke, 1965), since such factors influence the relative rates of production and utilization of ammonia by rumen micro-organisms. The extent of catabolism of newly absorbed or endo-

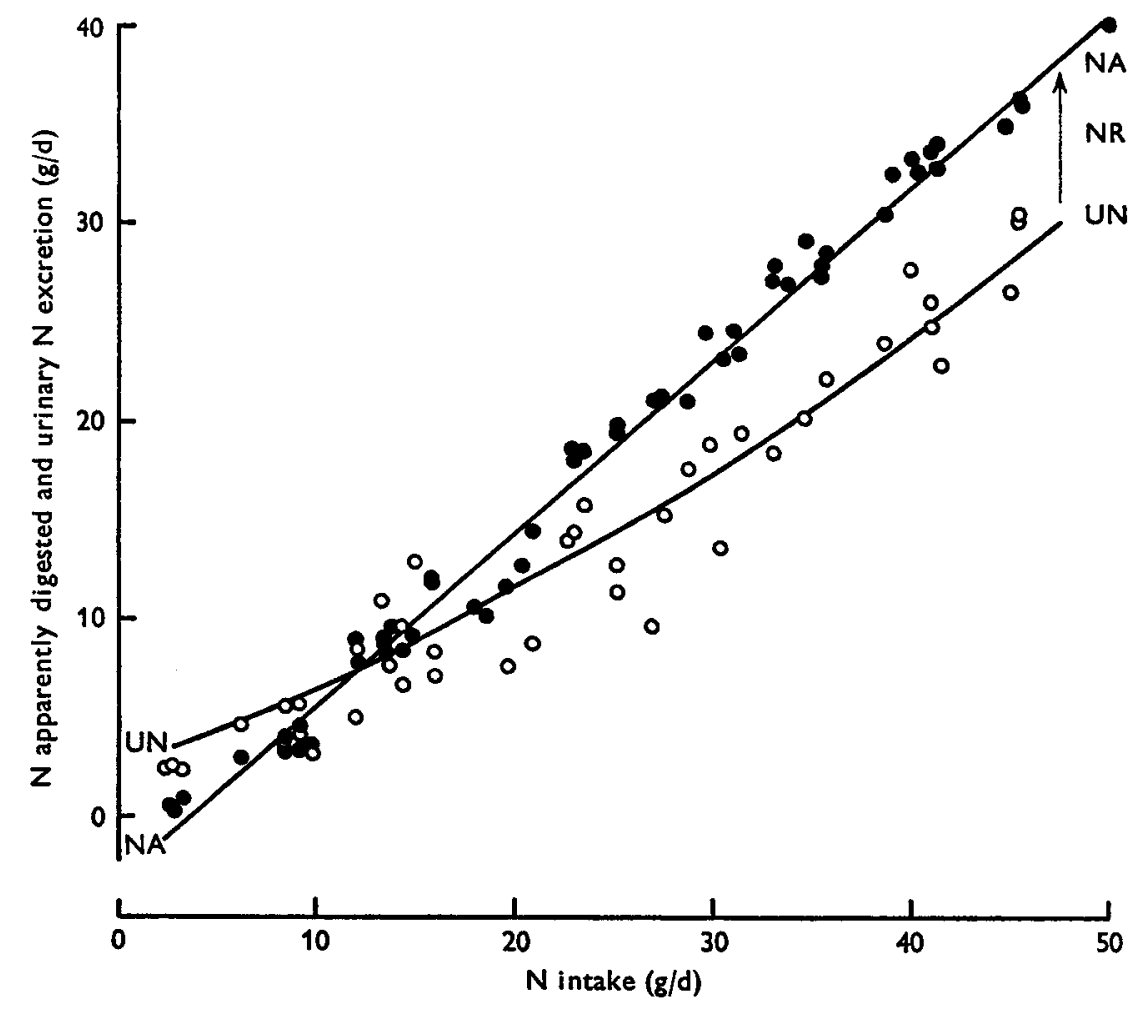

Fig. 1. General relationships, in sheep, between the intake, apparent absorption, urinary excretion and retention of herbage nitrogen. Equations are given on p. 339. , apparently digested $\mathrm{N}(\mathrm{NA}) ; \mathrm{O}$, urinary $\mathrm{N}$ excretion (UN); $\mathrm{NR}$, retained $\mathrm{N}$.

genous amino acids, depending on the physiological state of the animal, the availability of energy and the balance between amino acids, will affect urinary $\mathrm{N}$ losses. The concentrations of metabolites which may act as indices of the extent of these processes were examined, to determine whether any one metabolite or combination of metabolites would significantly improve the evaluation of $\mathrm{N}$ utilization, compared with estimates based on $\mathrm{N}$ intake.

\section{Concentrations of intraruminal and plasma $N$ metabolites in relation to $N$ concentration in the diet, $N$ intake, and $N$ apparently digested}

The relationships between concentrations of intraruminal and plasma $\mathrm{N}$ metabolites and the amount of $\mathrm{N}$ and apparently digestible $\mathrm{N}$ ingested, or the $\mathrm{N}$ concentra- 
tion of the diet are shown in Table 2. Though ruminal ammonia concentrations at each sampling time were significantly correlated with dietary $\mathbf{N}$ intake and with $\mathrm{N}$ apparently digested, the best relationships at $\mathrm{T}_{0}$ accounted for only 56 and $62 \%$ of the variability in ruminal ammonia $\mathrm{N}$ concentrations. Stronger positive correlations existed between ruminal ammonia $\mathrm{N}$ concentration and the dietary $\mathrm{N}$ content ( $\mathrm{g} \mathrm{N} / \mathrm{roo} \mathrm{g}$ organic matter or $\mathrm{g} \mathrm{N} / \mathrm{roo} \mathrm{g}$ digestible organic matter), though the best relationship accounted for only $74 \%$ of variability in ruminal ammonia $\mathrm{N}$ concentration. These results (Fig. 2) suggest the importance of dietary $\mathrm{N}$ concentration, or of
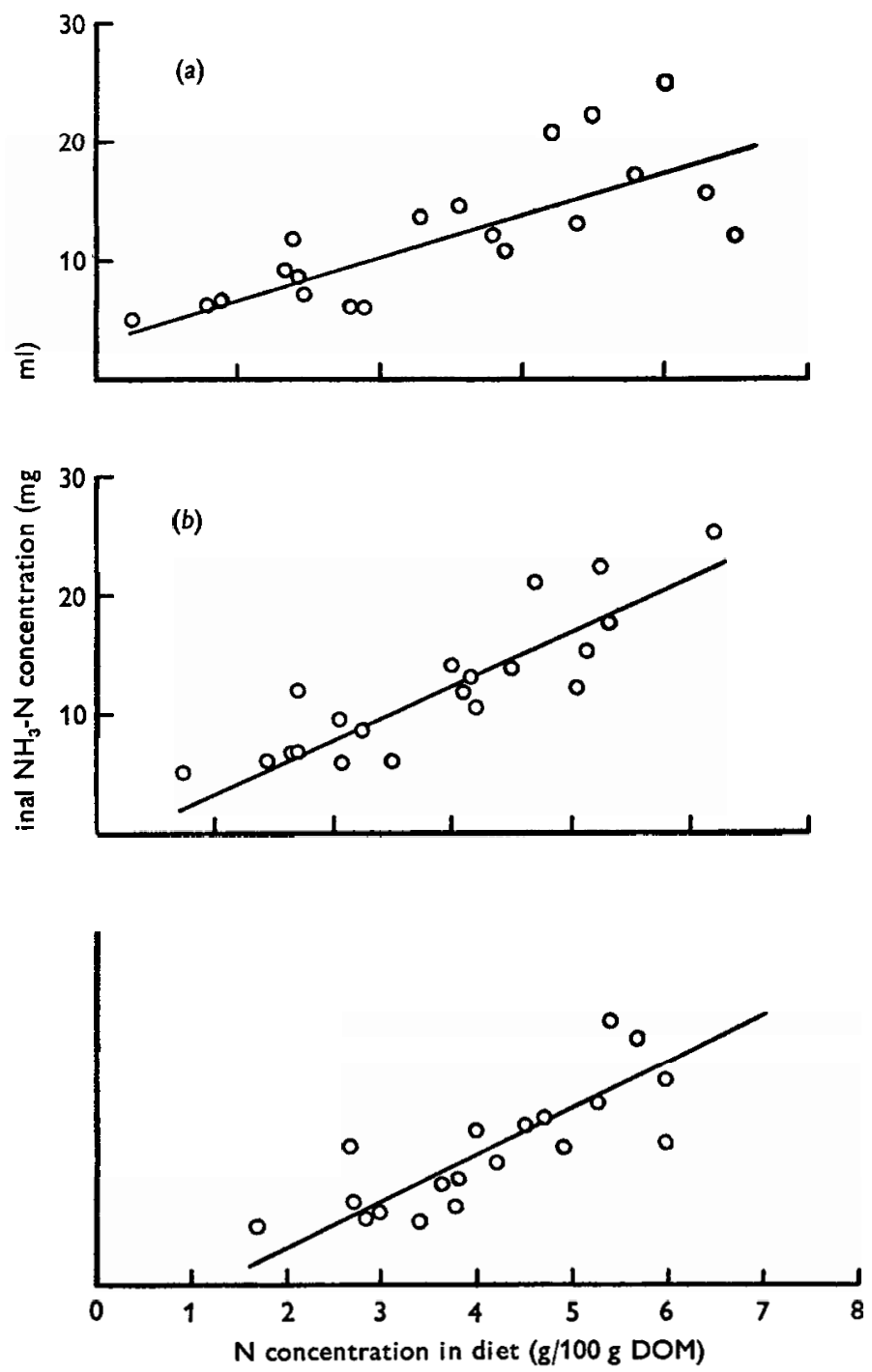

Fig. 2. Relationships, in sheep, between ruminal ammonia nitrogen concentration (RA) at $\mathbf{T}_{0}$ immediately before feeding (means for three sheep) and: (a) N intake (NI); (b) N concentration in the diet, per $100 \mathrm{~g}$ organic matter (N/OM); $(c) \mathrm{N}$ concentration in the diet, per $100 \mathrm{~g}$ digestible organic matter (N/DOM). Equations: $\mathrm{RA}_{0}=0.35 \mathrm{NI}+3.26 \pm 4.37 ; \mathrm{RA}_{0}=$ $4.50(\mathrm{~N} / \mathrm{OM})-1.32 \pm 3.22 ; \mathrm{RA}_{0}=3.89$ (N/DOM) $-4.83 \pm 3.50$. 
the organic-matter dilution of $\mathrm{N}$, in determining ruminal ammonia accumulation levels, but differ in some degree from the results of Weston \& Hogan (I968). They found, for a range of hays and sun-cured pasture herbages offered intermittently at $90 \%$ of ad lib. intakes, that ruminal ammonia concentration was more closely related to $\mathrm{N}$ content per $100 \mathrm{~g}$ digestible organic matter than to $\mathrm{N}$ content per $100 \mathrm{~g}$ organic matter. The advantage of inclusion of a digestibility term is consistent with the concept that energy made available during fermentation of organic matter is a major determinant of the efficiency of incorporation of ammonia into microbial protein. No

Table 2. Interrelationships, in sheep, between dietary nitrogen concentration, $N$ intake, $N$ apparently digested, and specific metabolite concentrations at three sampling times, immediately before feeding $\left(T_{0}\right)$ and at $\mathrm{I}\left(T_{1}\right)$ and $4\left(T_{4}\right) h$ after feeding

(Relationships are expressed using the statistic $r^{2} \times 100$, which represents the percentage of variability in one variable which can be accounted for by variability in a second variable; $r^{2}$ is the square of the correlation coefficient)

\begin{tabular}{|c|c|c|c|c|c|c|c|c|c|}
\hline \multirow[b]{2}{*}{ Variable } & \multicolumn{3}{|c|}{$\begin{array}{c}\text { Ruminal } \mathrm{NH}_{3}-\mathrm{N} \\
\text { concentration }\end{array}$} & \multicolumn{3}{|c|}{$\begin{array}{l}\text { Ruminal TCA-N } \\
\text { concentration }\end{array}$} & \multicolumn{3}{|c|}{$\begin{array}{c}\text { Plasma urea-N } \\
\text { concentration }\end{array}$} \\
\hline & $\mathrm{T}_{0}$ & $\mathrm{~T}_{1}$ & $\mathrm{~T}_{4}$ & $\mathrm{~T}_{0}$ & $\mathrm{~T}_{1}$ & $\mathrm{~T}_{4}$ & $T_{0}$ & $\mathrm{~T}_{1}$ & $\mathrm{~T}_{4}$ \\
\hline $\begin{array}{l}\mathrm{N} \text { concentration in diet } \\
(\% \text { OM }) \\
(\% \mathrm{DOM})\end{array}$ & $\begin{array}{l}74 \\
7 \mathrm{I}\end{array}$ & $\begin{array}{l}64 \\
66\end{array}$ & $\begin{array}{l}63 \\
64\end{array}$ & $\dot{\cdot}$ & · & $\dot{.}$ & $\dot{\cdot}$ & $\dot{\cdot}$ & $\dot{.}$ \\
\hline $\mathrm{N}$ intake & $5^{6}$ & 41 & 45 & 55 & $5^{6}$ & 54 & $4 ð$ & 59 & 62 \\
\hline $\mathrm{N}$ apparently digested & 62 & 47 & 48 & 59 & $5^{8}$ & $5^{8}$ & $5 \mathbf{I}$ & 60 & 66 \\
\hline $\begin{array}{l}\text { Ruminal } \mathrm{NH}_{3}-\mathrm{N} \text { con- } \\
\text { centration }\end{array}$ & & & & & & & & & \\
\hline $\mathrm{T}_{0}$ & - & - & . & 29 & . & . & 69 & . & . \\
\hline $\mathrm{T}_{1}$ & . & . & . & $\cdot$ & $4 \mathrm{I}$ & • & $\cdot$ & 52 & - \\
\hline $\mathrm{T}_{4}$ & - & . & . & . & $\cdot$ & 22 & - & . & 56 \\
\hline $\begin{array}{l}\text { Ruminal TCA-N } \\
\text { concentration }\end{array}$ & & & & & & & & & \\
\hline $\mathrm{T}_{0}$ & . & . & . & . & . & . & 15 & $0^{\circ}$ & . \\
\hline$T_{1}$ & . & · & - & - & . & . & · & 28 & . \\
\hline $\mathrm{T}_{4}$ & . & - & . & . & . & . & . & . & 29 \\
\hline
\end{tabular}

OM, organic matter; DOM, digestible organic matter.

such advantage was found in our results. It is possible that in our study, with a wider range of diets offered under conditions approaching ad lib. intake, availability of energy substrates at the time of maximum rate of protein fermentation was not as well related to the total digestibility of the organic matter as appeared to be the situation under the conditions imposed by Weston \& Hogan (I968).

The concentration of TCA-N at each sampling time was significantly and positively correlated with both $\mathrm{N}$ intake and $\mathrm{N}$ apparently digested, though at best the relationships accounted for only 54 and $58 \%$ of the variability in TCA-N concentration respectively.

The observed poor relationships between intake of $\mathrm{N}$ or apparently digested $\mathrm{N}$, and ammonia $\mathrm{N}$ concentration or TCA-N concentration in ruminal digesta may arise from real differences in the rate and extent of fermentation of protein, which would 
confirm the need to evaluate the usefulness of herbage $\mathrm{N}$ on bases other than $\mathrm{N}$ intake or herbage $\mathrm{N}$ concentration. Alternatively, it may arise simply from inadequacies of sampling, which would indicate a need for caution in the use of digesta metabolites as indices of $\mathrm{N}$ utilization except where adequate digesta mixing and sampling techniques can be applied. Evaluation of these two separate sources of variation is not possible here. Though Tagari et al. (1964) have suggested that fluctuations in rumen volume should not affect the reliability of estimates based upon rumen metabolites, variations in rates of feed ingestion and in times of water consumption can influence the amount and composition of digesta present in the reticulo-rumen at sampling times. Such variations would always be likely under field conditions.

Plasma urea $\mathrm{N}$ concentration was positively correlated with $\mathrm{N}$ intake and $\mathrm{N}$ apparently digested (Table 2), though the strongest relationships, based upon plasma urea $\mathrm{N}$ concentration at $\mathrm{T}_{4}$, accounted for only 62 and $66 \%$ of variability in plasma urea $\mathrm{N}$ concentration respectively. Much stronger relationships between serum urea level and crude protein intake $\left(r^{2}=0.996\right)$ or digestible crude protein intake $\left(r^{2}=\right.$ 0.986 ) were reported by Ide, Shimbayashi \& Yonemura (1967), for sheep offered a narrow range of diets with energy intake held constant. Nevertheless, in our results, where the observed ruminal ammonia or plasma urea concentration was greater than the value predicted from regression equations based upon $\mathrm{N}$ intake, the observed urinary $\mathrm{N}$ output was also greater than the value predicted from the regression of urinary $\mathrm{N}$ on $\mathrm{N}$ intake. This suggested that a part of the variability in the metabolite values not accounted for by variability in $\mathrm{N}$ intake was associated with differences in efficiency of $\mathrm{N}$ utilization.

Plasma total amino acid concentrations showed no correlation with $\mathrm{N}$ intake or $\mathrm{N}$ absorbed and actual values for $r^{2}$ are not given in Table 2. At low levels of $\mathrm{N}$ intake, when animals were in negative $\mathrm{N}$ balance, total amino acid concentrations were often as high as in animals ingesting five times as much $\mathrm{N}$ and retaining up to $8-\mathrm{I} \circ \mathrm{g} \mathrm{N} / \mathrm{d}$.

\section{Relationships between intraruminal $N$ metabolites and plasma $N$ metabolites}

Relationships between the concentrations of ammonia $\mathrm{N}$ and TCA-N in ruminal digesta, and urea $\mathrm{N}$ at the various sampling times are shown in Table 2. The changes in concentration of ammonia $\mathrm{N}$ or plasma urea $\mathrm{N}$ occurring over the first $4 \mathrm{~h}$ after feeding were poorly correlated with the concentrations of the respective metabolites before feeding, resembling in this aspect the results presented by Abou Akkada \& Osman (1967), and actual values are not given in the table. In the further examination: of relationships between metabolite concentrations and $\mathrm{N}$ utilization, the concentra tions of metabolites before feeding and the increments occurring after feeding were treated in multiple regressions as independent variables.

Though ruminal digesta concentrations of ammonia $\mathrm{N}$ and TCA-N were significantly and positively correlated at each time of sampling, the concentrations of ruminal ammonia $\mathrm{N}$ were far more mobile than were the concentrations of TCA-N, rising 
more rapidly than TCA-N during the Ist hour after feeding, and falling more rapidly during the next $3 \mathrm{~h}$ to $\mathrm{T}_{4}$ (Table 3 ).

Ruminal ammonia $\mathrm{N}$ and plasma urea $\mathrm{N}$ concentrations were positively correlated, though at best only $69 \%$ of the variability in concentration of one metabolite could be accounted for by the variability in concentration of the other. Ruminal ammonia $\mathrm{N}$ concentrations rose more rapidly than plasma urea $\mathrm{N}$ concentrations during the Ist hour after feeding, and subsequently fell more rapidly (Fig. 3).

Table 3. Relationships, in sheep, between ruminal ammonia nitrogen concentration $(R A, m g N / 100 m l)$, concentration of $T C A$-precipitable $N$ in ruminal digesta ( $T N$, $m g N / 100 m l)$, and plasma urea $N$ concentration $(P U N, m g N / 100 m l)$ at three times of sampling, shown by subscript o (immediately before feeding), subscript I (at I $h$ after feeding) and subscript 4 (at $4 h$ after feeding)

$\begin{array}{lc} & \text { SD } \\ \mathrm{RA}_{0}=0.05 \mathrm{TN}_{0}+5.63 & 5.07 \\ \mathrm{RA}_{1}=0.1 \mathrm{~T} \mathrm{TN}_{1}+8.59 & 7.19 \\ \mathrm{RA}_{4}=0.07 \mathrm{TN}_{4}+8.63 & 9.2 \mathrm{I} \\ \mathrm{RA}_{0}=\mathrm{I} \cdot 36 \mathrm{PUN}_{0}-2.10 & 3.3 \mathrm{I} \\ \mathrm{RA}_{1}=\mathrm{I} .39 \mathrm{PUN}_{1}+3.28 & 6.54 \\ \mathrm{RA}_{4}=\mathrm{I} \cdot 74 \mathrm{PUN}_{4}-5.08 & 6.87 \\ \mathrm{PUN}_{0}=0.02 \mathrm{TN}_{0}+7.42 & 3.40 \\ \mathrm{PUN}_{1}=0.05 \mathrm{TN}_{1}+7.33 & 4.10 \\ \mathrm{PUN}_{4}=0.04 \mathrm{TN}_{4}+8.50 & 3.80\end{array}$

Relationships between plasma urea $\mathrm{N}$ concentration and TCA-N at individual sampling times were poor, and plasma total amino acid concentrations were not significantly correlated with the concentrations of ammonia $\mathrm{N}$ or TCA-N in the ruminal digesta or of urea $\mathrm{N}$ in plasma.

\section{Relationships between urinary $N$ output and $N$ metabolites in ruminal digesta and plasma}

The relationships between ruminal ammonia $\mathrm{N}$, TCA-N and plasma urea $\mathrm{N}$, and urinary $\mathrm{N}$ output are shown in Table 4 . Plasma total $\alpha$-amino $\mathrm{N}$ accounted for only $\mathbf{I}-\mathbf{2} \%$ of the variability in urinary $\mathrm{N}$ and in $\mathrm{N}$ retention.

Urinary $\mathrm{N}$ output and ruminal ammonia concentration at each time of sampling were positively correlated though with values after feeding residual variability was greater. Stronger relationships were found between urinary $N$ output and plasma urea $\mathrm{N}$ concentration at each sampling time, the best relationship, with plasma urea $\mathrm{N}$ concentration at $\mathrm{T}_{4}$, accounting for $74 \%$ of the variability in urinary $\mathrm{N}$ output.

Abou Akkada \& Osman ( 1967 ) reported relationships between urinary $N$ output and the increments in ruminal ammonia or in plasma urea concentrations during the 3-4 $\mathrm{h}$ after feeding, expressing urinary $\mathrm{N}$ output as the percentage of the ingested $\mathrm{N}$ which was excreted in the urine. The relationships between these variables appeared stronger for legumes than that for grasses. Though correlation coefficients were highly significant, the standard errors of prediction were also high throughout their results. In our experiment the increment in ruminal ammonia $\mathrm{N}$ or in plasma urea $\mathrm{N}$ con- 
centration over $\mathrm{rh}$ or $4 \mathrm{~h}$ after feeding, each taken as the independent variable in simple regression, was not significantly related to urinary $N$ outputs $\left(r^{2}=0 \cdot 18\right)$, or to the percentage of ingested $\mathrm{N}$ excreted in the urine $\left(r^{2}=0 \cdot 06\right)$.

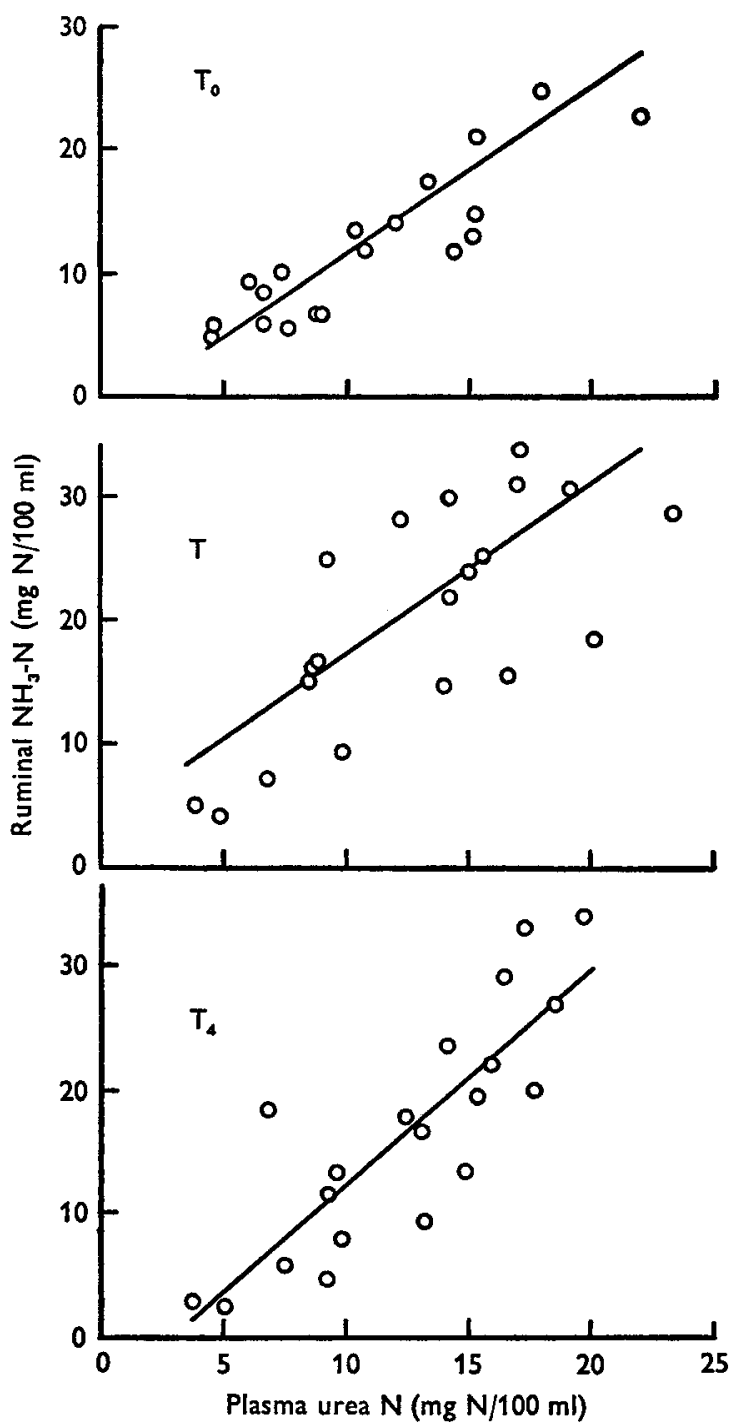

Fig. 3. Relationships, in sheep, between ruminal ammonia nitrogen concentration and plasma urea $\mathrm{N}$ concentration at each of three sampling times, immediately before feeding $\left(\mathrm{T}_{0}\right), 1 \mathrm{~h}$ after feeding $\left(T_{1}\right)$ and $4 \mathrm{~h}$ after feeding $\left(\mathrm{T}_{4}\right)$. Equations are given in Table 3.

We consider this particular form of relationship to be inappropriate when examining $\mathrm{N}$ utilization over a wide range of diets, for the following reasons. Urinary $\mathrm{N}$ output as a percentage of $\mathrm{N}$ intake is itself strongly dependent upon the level of $\mathrm{N}$ intake. At low levels of $\mathrm{N}$ intake the urinary $\mathrm{N}$ output as a percentage of $\mathrm{N}$ intake is high because of endogenous $\mathrm{N}$ components in the urine; at high levels of $\mathrm{N}$ intake, $\mathrm{N}$ is 
utilized with lower efficiency, again resulting in a high percentage of the ingested $\mathrm{N}$ appearing in the urine. At some intermediate point, $\mathrm{N}$ utilization is at highest efficiency and urinary $\mathrm{N}$ output as a percentage of $\mathrm{N}$ intake is at a minimum. The relationship between the $\mathrm{N}$ intake and the percentage of the ingested $\mathrm{N}$ which is excreted in the urine is thus parabolic. Such a relationship appears to hold for our results (Fig. 4). In contrast, plasma urea concentrations and the increment in plasma urea after feeding tend to increase with $\mathrm{N}$ intake and, although there is wide variability, there is no evidence to suggest a parabolic relationship between these variables, at least

Table 4. Simple relationships, in sheep, between urinary nitrogen output, or $N$ retained and specific metabolite concentrations at three sampling times, $T_{0}$ (immediately before feeding) $T_{1}$ (I $h$ after feeding) and $T_{4}$ ( $4 h$ after feeding)

(Relationships are expressed using the statistic $r^{2} \times 100$, which represents the percentage of variability in one variable which can be accounted for by variability in a second variable; $r^{2}$ is the square of the correlation coefficient)

\begin{tabular}{|c|c|c|c|c|c|c|c|c|c|c|c|}
\hline & \multicolumn{3}{|c|}{$\begin{array}{c}\text { Ruminal } \mathrm{NH}_{3}-\mathrm{N} \\
\text { concentration }\end{array}$} & \multicolumn{3}{|c|}{$\begin{array}{c}\text { TCA-N } \\
\text { concentration }\end{array}$} & \multicolumn{5}{|c|}{$\begin{array}{l}\text { Plasma urea } \mathrm{N} \\
\text { concentration }\end{array}$} \\
\hline & $\mathrm{T}^{0}$ & $\mathrm{~T}_{1}$ & $\mathrm{~T}_{4}$ & $\mathrm{~T}_{\mathrm{o}}$ & $\mathrm{T}_{1}$ & $\mathrm{~T}_{4}$ & $T_{0}$ & $\mathrm{~T}_{\mathbf{1}}$ & $\mathrm{T}_{4}$ & $\Delta T_{1}$ & $\Delta \mathrm{T}_{4}$ \\
\hline $\begin{array}{l}\text { Urinary } N \\
\text { UN/NI }\end{array}$ & 59 & 53 & 48 & 33 & 42 & 34 & $6 I$ & 69 & 74 & $\begin{array}{r}17 \\
6\end{array}$ & $\begin{array}{r}16 \\
6\end{array}$ \\
\hline $\begin{array}{l}\text { N retained } \\
\text { NR/NI }\end{array}$ & 30 & 29 & 24 & 45 & 29 & 35 & 8 & 24 & $3 I$ & $\begin{array}{r}22 \\
5\end{array}$ & $\begin{array}{r}36 \\
7\end{array}$ \\
\hline
\end{tabular}

$\Delta T_{1}$, change in concentration between sampling times $T_{0}$ and $T_{1}$.

$\Delta T_{4}$, change in concentration between sampling times $T_{0}$ and $T_{4}$.

$\mathrm{UN} / \mathrm{NI}$, urinary $\mathrm{N}$ output as a percentage of $\mathrm{N}$ intake.

$\mathrm{NR} / \mathrm{NI}, \mathrm{N}$ retained as a percentage of $\mathrm{N}$ intake.

over the wide range of $\mathrm{N}$ intakes in our study. The relationship used by Tagari et al. (1964) and Abou Akkada \& Osman (1967), which predicts urinary $\mathrm{N}$ output as a percentage of $\mathrm{N}$ intake to increase linearly as plasma urea concentration or the increment in plasma urea concentration rises, is therefore strongly subject to the range of dietary $\mathrm{N}$ intake, the correlation becoming poorer as more diets providing low $\mathrm{N}$ intakes are included in the range. This may explain the fact that in the results of Abou Akkada \& Osman (1967) the relationship was stronger for legumes, when $\mathrm{N}$ intakes were generally higher, than for grasses. Each such relationship thus developed would need to be regarded as specific, rather than general. For this reason, prediction of absolute amounts of $\mathrm{N}$ excreted in the urine appears to be essentially more satisfactory in any equation developed to have general application.

In multiple regression equations which included as independent variables the plasma urea $\mathrm{N}$ concentration before feeding and the increments in plasma urea $\mathrm{N}$ concentration at $\mathrm{I} \mathrm{h}$ and $4 \mathrm{~h}$ after feeding, each successive term contributed significantly to the prediction of urinary N. Despite this, the residual error associated with the multiple regression equation was not significantly lower than those associated with equations based upon values at any single sampling time (Table 5). Similar multivariate equations predicting urinary $\mathrm{N}$ output from ruminal ammonia $\mathrm{N}$ concentrations were not significantly better than simple regression equations based upon 
ruminal ammonia $\mathrm{N}$ concentrations before feeding. Thus, although the increments in ruminal ammonia $\mathrm{N}$ or in plasma urea $\mathrm{N}$ concentration after feeding varied widely, these variations did not appear to be reflected in a consistent or statistically significant way by urinary $\mathrm{N}$ losses.
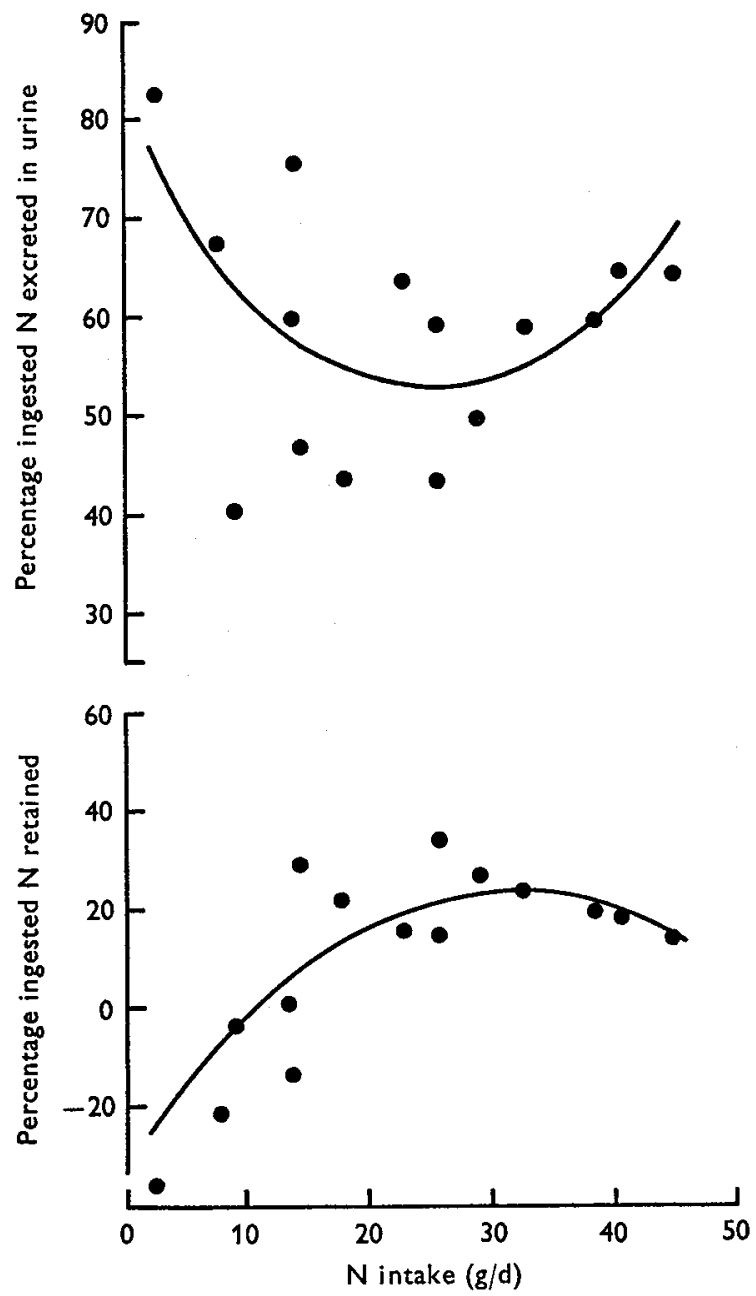

Fig. 4. IRelationships, in sheep, between percentage of ingested nitrogen excreted in urine $(\mathrm{UN} / \mathrm{NI})$ and percentage of ingested $\mathrm{N}$ retained $(\mathrm{NR} / \mathrm{NI})$, and $\mathrm{N}$ intake $(\mathrm{NI})$. UN/NI = $80.0-2.23 \mathrm{NI}+0.044 \mathrm{NI}^{2} \pm 12 \cdot \mathrm{I} \quad\left(r^{2}=0.24\right) ; \quad \mathrm{NR} / \mathrm{NI}=3.54 \mathrm{NI}-0.055 \mathrm{NI}^{2}-33.0 \pm 20.3$ $\left(r^{2}=0.32\right)$.

Despite a general relationship between $\mathrm{N}$ losses in the urine and $\mathrm{N}$ intake, it appeared that, where urinary $\mathrm{N}$ losses were greater than predicted for a given $\mathrm{N}$ intake, relatively high concentrations of ruminal ammonia $\mathrm{N}$ and plasma urea $\mathrm{N}$ were observed before feeding, or large increments were developed after feeding. Multiple regressions were examined to determine whether metabolite concentrations were an effective index of the urinary $\mathrm{N}$ loss at a given $\mathrm{N}$ intake. Results are shown in 
Table 5. Inclusion of values for ruminal ammonia $\mathrm{N}$ concentrations at any single sampling or the increments after feeding did not improve the prediction of urinary $\mathrm{N}$ losses based upon $\mathrm{N}$ intake; residual standard errors were reduced by only $\mathrm{I} \%$. There is thus no evidence in our results that at a given $\mathrm{N}$ intake, the urinary $\mathrm{N}$ output was increased in proportion to the concentration of ruminal ammonia $\mathrm{N}$ at any single time, or in proportion to the increment in ruminal ammonia $\mathrm{N}$ concentrations in the first $4 \mathrm{~h}$ after feeding.

Table 5. Equations for prediction, in sheep, of urinary nitrogen output derived from simple regressions on individual metabolites, or from multiple regressions, including metabolite concentration changes*

(Equations are best-fit equations for each metabolite, in each type of relationship. Times of sampling are shown as subscripts: 0 , immediately before feeding; $I$, at $\mathrm{I} \mathrm{h}$ after feeding; 4 , at $4 \mathrm{~h}$ after feeding)

$$
\begin{array}{lr}
\mathrm{UN}=1 \cdot 09 \mathrm{RA}_{0}+0.94 \pm 5.2 \mathrm{I} & \left(r^{2}=0.59\right) \\
\mathrm{UN}=1 \cdot 57 \mathrm{PUN}_{4}-6.24 \pm 4.16 & \left(r^{2}=0.74\right) \\
\mathrm{UN}=0.89 \mathrm{RA}_{0}+0.23 \Delta \mathrm{RA}_{0-1}+0.07 \Delta \mathrm{RA}_{1-4}+0.75 \pm 5.49 & \left(r^{2}=0.56\right) \\
\mathrm{UN}=1 \cdot 58 \mathrm{PUN} \mathrm{N}_{1}+1 \cdot 40 \Delta \mathrm{PUN}_{0-1}+0.96 \Delta \mathrm{PUN} \mathrm{N}_{1-4}-5.79 \pm 4.42 & \left(r^{2}=0.73\right) \\
\mathrm{UN}=1 \cdot 60 \mathrm{PUN} \mathrm{N}_{1}+\mathrm{I} \cdot 24 \Delta \mathrm{PUN}_{0-4}-5.56 \pm 4.56 & \left(r^{2}=0.69\right) \\
\mathrm{UN}=0.26 \mathrm{NI}+0.006 \mathrm{NI}^{2}+0.17 \mathrm{RA}_{0}+2 \cdot 15 \pm 3.04 & \left(r^{2}=0.87\right) \\
\mathrm{UN}=0.17 \mathrm{NI}+0.007 \mathrm{NI}^{2}+0.5 \mathrm{IUN}_{0}+0.29 \pm 2.78 & \left(r^{2}=0.90\right)
\end{array}
$$

UN, urinary $N$ output; RA, ruminal ammonia $N$ concentration; PUN, plasma urea $N$ concentration; NI, $\mathrm{N}$ intake.

- $\Delta \mathrm{RA}_{0-1}$, change in ruminal ammonia $N$ concentration between sampling times $T_{0}$ and $T_{1}$.

Inclusion of values for plasma urea $\mathrm{N}$ concentration at any single sampling time, but not for the increments after feeding, reduced the residual standard errors for prediction of urinary $\mathrm{N}$ output based on $\mathrm{N}$ intake by $10 \%$. In this respect the most effective values were those for plasma urea $\mathrm{N}$ concentration before feeding. Though barely significant statistically, the biological implication is that, at a given level of $\mathrm{N}$ intake, plasma urea $\mathrm{N}$ values may improve prediction of urinary $\mathrm{N}$ losses. In this respect values for plasma urea $N$ concentration were more reliable as an index of efficiency of $\mathrm{N}$ utilization than values for ruminal ammonia $\mathrm{N}$ concentration.

\section{Relationships between $N$ retention and $N$ metabolites in the ruminal digesta or in the plasma}

The relationships between respective $\mathrm{N}$ metabolites and $\mathrm{N}$ retention are shown in Table 4.

$\mathrm{N}$ retention was significantly correlated with TCA-N concentration in the rumen before feeding (Table 4). Apart from this one instance, no metabolite measured showed a significant direct correlation with $\mathrm{N}$ retention. The most effective estimates of $\mathrm{N}$ retention were derived from multiple regressions including either the plasma urea $\mathrm{N}$ concentration before feeding and the increments in plasma urea $\mathrm{N}$ concentration following feeding, or, alternatively, plasma urea $\mathrm{N}$ concentration as a multiple variate with $\mathrm{N}$ intake (Table 6). 
It could be predicted from the multiple regression equations that an animal would achieve zero $\mathrm{N}$ retention ( $\mathrm{N}$ equilibrium) if plasma urea $\mathrm{N}$ concentration before feeding was about $8 \mathrm{mg} / 100 \mathrm{ml}$. The minimum plasma urea $\mathrm{N}$ concentration expected at $\mathrm{T}_{0}$ for animals in positive $\mathrm{N}$ balance was $5 \mathrm{mg} / \mathrm{x} 00 \mathrm{ml}$, and the maximum concentration expected at $\mathrm{T}_{0}$ for animals in negative $\mathrm{N}$ balance was $\mathrm{I} 2 \mathrm{mg} / \mathrm{I00} \mathrm{ml}$. Part of this variation was accounted for by differences in the extent of increases in plasma urea $\mathrm{N}$ concentration after feeding. A similar $\mathrm{N}$ balance would be achieved if, for each $\mathrm{I} \mathrm{mg} /$ $100 \mathrm{ml}$ increase in the concentration of plasma urea $\mathrm{N}$ before feeding, there was a I $\mathrm{mg} / \mathrm{I} 00 \mathrm{ml}$ decrease in the increment in plasma urea $\mathrm{N}$ concentration measured at a sampling $4 \mathrm{~h}$ after feeding. However, this type of relationship accounted for only $62 \%$ of the variability in $\mathrm{N}$ retention.

Table 6. Equations for prediction, in sheep, of nitrogen retention derived from simple regressions on individual metabolites or multiple regressions including metabolite concentration changes*

(Equations are best-fit equations for each metabolite in each type of relationship. Times of sampling are shown as subscripts: 0 , immediately before feeding; $\mathrm{I}, \mathrm{I} \mathrm{h}$ after feeding; $4,4 \mathrm{~h}$ after feeding)

$$
\begin{aligned}
& \mathrm{NR}=0.46 \mathrm{RA}_{0}-2.33 \pm 4.19 \\
& \mathrm{NR}=0.62 \mathrm{PUN}_{4}-4.75 \pm 4.13 \\
& \mathrm{NR}=0.053 \mathrm{TN}_{0}-3.33 \pm 3.72 \\
& \mathrm{NR}=0.37 \mathrm{RA}_{0}+2 \cdot 27 \Delta \mathrm{RA}_{0-1} * 2 \cdot 88 \pm 2 \cdot 5 \mathrm{I} \\
& N R=0.36 R A_{0}+0.20 \Delta R_{0-4}-1.45 \pm 2.63 \\
& \mathrm{NR}=0.68 \mathrm{PUN}_{0}+0.70 \Delta \mathrm{PUN}_{0-1}+0.53 \Delta \mathrm{PUN}_{1-4}-4.73 \pm 2.50 \\
& \mathrm{NR}=0.69 \mathrm{PUN}_{0}+0.64 \Delta \mathrm{PUN}_{0-4}-4.69 \pm 2.52 \\
& \mathrm{NR} / \mathrm{NI}=2 \cdot 40 \mathrm{PUN}_{4}-19 \cdot 40 \pm 2 \mathrm{I} \cdot 7 \\
& \mathrm{NR}=0.16 \mathrm{NI}+0.14 \mathrm{RA}_{0}+0.18 \Delta \mathrm{RA}_{0-1}-3.14 \pm 2.20 \\
& \mathrm{NR}=0.36 \mathrm{NI}-0.4 \mathrm{IPUN}_{0}-0.99 \pm 2.32 \\
& \mathrm{NR}=0.20 \mathrm{NA}+0.1 \mathrm{IRA} \mathrm{A}_{0}+0.16 \Delta \mathrm{R} \mathrm{A}_{0-1}-2 \cdot 38 \pm 2 \cdot 19 \\
& \mathrm{NR}=0.43 \mathrm{NA}-0.47 \mathrm{PUN}_{0}+0.56 \pm 2.15 \\
& \mathrm{NR}=0.56 \mathrm{FN}+0.30 R A_{0}+0.25 \Delta \mathrm{RA}_{0-1}-5.22 \pm 2.34 \\
& \begin{array}{l}
\left(r^{2}=0.29\right) \\
\left(r^{2}=0.3 \mathrm{I}\right) \\
\left(r^{2}=0.45\right) \\
\left(r^{2}=0.6 \mathrm{I}\right) \\
\left(r^{2}=0.58\right) \\
\left(r^{2}=0.62\right) \\
\left(r^{2}=0.6 \mathrm{I}\right) \\
\left(r^{2}=0.20\right) \\
\left(r_{2}=0.7 \mathrm{I}\right) \\
\left(r^{2}=0.68\right) \\
\left(r^{2}=0.72\right) \\
\left(r^{2}=0.72\right) \\
\left(r^{2}=0.67\right)
\end{array}
\end{aligned}
$$

NR, nitrogen retention; RA, ruminal ammonia $N$ concentration; PUN, plasma urea $N$ concentration; $T N$, concentration of TCA-precipitable $\mathrm{N}$ in ruminal digesta; NR/NI, $\mathrm{N}$ retained as a percentage of $\mathrm{N}$ intake.

Prediction of $\mathrm{N}$ retained from $\mathrm{N}$ intake or $\mathrm{N}$ apparently digested was improved by inclusion of the values for plasma urea $\mathrm{N}$ before feeding but the inclusion of additional terms for increments in plasma urea $\mathrm{N}$ after feeding did not further improve the estimate. Estimates of $\mathrm{N}$ retained from equations based on faecal $\mathrm{N}$ output were improved significantly by successive inclusion of terms for plasma urea $\mathrm{N}$ concentration before feeding and increments at $T_{1}$, though the coefficient attached to the faecal $\mathrm{N}$ became progressively smaller and the equation is in essence identical with that relating $\mathrm{N}$ retention directly to plasma urea $\mathrm{N}$ values (Table 6 ) and has a similar residual error.

Similar relationships based upon results for ruminal ammonia $\mathrm{N}$ concentration had similar residual errors (Table 6).

The above relationships were developed for prediction of $\mathrm{N}$ retention in absolute terms. Tagari et al. (1964) and Abou Akkada \& Osman (1967) developed linear equations to predict the percentage of ingested $\mathrm{N}$ retained from the change in plasma 
urea or ruminal ammonia concentrations during approximately $4 \mathrm{~h}$ after feeding. In our study relationships between the concentration of plasma urea $\mathrm{N}$ at any sampling time, or the increments in plasma urea $\mathrm{N}$ concentration after feeding, and the percentage of ingested $\mathrm{N}$ retained were poor (Table 4), the best relationship accounting for less than $25 \%$ of the variability in the percentage of ingested $\mathrm{N}$ retained. For reasons outlined already, low efficiency of $\mathrm{N}$ retention occurs at both high and low $\mathrm{N}$ intakes and it is not necessarily reflected at both ends of the $\mathrm{N}$ intake range by similar high ruminal ammonia or plasma urea concentrations. In our results an approximate point of maximal efficiency of $\mathrm{N}$ retention appeared to be reached at intakes of 25-30 g N (20-24 $\mathrm{g} \mathrm{N}$ absorbed) (Fig. 4). The position of this point in any dietary series depends upon the nature of the dietary $\mathrm{N}$, the availability of energy and the nutritional and physiological condition of the animal (cf. Robinson \& Forbes, 1967). Linear equations for prediction of the amount of $\mathrm{N}$ retained as a percentage of $\mathrm{N}$ intake from ruminal ammonia or plasma urea concentration changes do not have general application. The equations produced from any single experiment will be unique, depending on the range of $\mathrm{N}$ intakes given, will not be demonstrably non-linear unless very large numbers of diets are used, will have extremely variable residual errors, and can have either positive or negative slopes.

\section{Conclusions}

The hypothesis tested was that within a particular class, age and weight range of sheep, the concentrations of selected $\mathrm{N}$ metabolites would act as indices of the current $\mathrm{N}$ metabolism in a systematic way and permit the rapid and accurate prediction of $\mathrm{N}$ utilization. From such an hypothesis, methods for estimating the efficiency of utilization of dietary $\mathrm{N}$ have been proposed by others (el-Shazly, I958; Tagari et al. I964; Abou Akkada \& Osman, 1967). Diets were chosen to give a wide range of patterns of $\mathrm{N}$ utilization. Urinary $\mathrm{N}$ excretion and $\mathrm{N}$ retention were not closely related to $\mathrm{N}$ intake, and the relationships between $\mathrm{N}$ intake and metabolite concentrations and also between the concentrations of the various $\mathrm{N}$ metabolites suggested that each metabolite might be treated independently as a potential index of processes of $\mathrm{N}$ utilization. Our results indicate that only within broad limits can urinary $\mathrm{N}$ losses and $\mathrm{N}$ retention be predicted from plasma urea $\mathrm{N}$ concentrations at a single sampling time under ad lib. feeding conditions. Though predictions may be improved by inclusion of information on changes in plasma urea $\mathrm{N}$ concentration during a specified interval of time after feeding, the best such relationships accounted for only $70 \%$ of the variability in urinary $\mathrm{N}$ output and $62 \%$ of variability in $\mathrm{N}$ retention. Ruminal ammonia $\mathrm{N}$ concentrations are a less effective basis for prediction of urinary $\mathrm{N}$ output, possibly because of sampling errors. For prediction of $\mathrm{N}$ retention, plasma urea $\mathrm{N}$ and ruminal ammonia $\mathrm{N}$ concentrations are equally poor. Concentrations of TCA-N in ruminal digesta and total amino acids in the plasma proved of little value, though TCA-N was the only metabolite significantly correlated with $\mathrm{N}$ retained in a simple regression.

Acceptable levels of accuracy of prediction may vary with the purpose to which the results are put, and at similar levels of $\mathrm{N}$ intake it remains possible that relative 
efficiency of $\mathrm{N}$ utilization can be determined, at least for ranking purposes, from such variables as plasma urea $\mathrm{N}$ concentration before feeding and the increments in plasma urea $\mathrm{N}$ concentration after feeding. If $\mathrm{N}$ intake is known, differences in concentrations of ruminal ammonia $\mathrm{N}$ or plasma urea $\mathrm{N}$ can account for a part of the variability in urinary $\mathrm{N}$ output or $\mathrm{N}$ retention not accounted for by $\mathrm{N}$ intake. The best equations, based on $\mathrm{N}$ intake and plasma urea $\mathrm{N}$ concentration before feeding, accounted for $90 \%$ of the variability in urinary $\mathrm{N}$ output, predicting urinary $\mathrm{N}$ with a standard error of $\pm 2.8 \mathrm{~g} \mathrm{~N} / \mathrm{d}$ (Table 5 ) but accounted for only $71 \%$ of the variability in $\mathrm{N}$ retained, predicting $\mathrm{N}$ retention with a standard error of $\pm 2 \cdot 3 \mathrm{~g} \mathrm{~N} / \mathrm{d}$.

If prediction equations are to be produced, it appears that these should relate to the amount of $\mathrm{N}$ excreted in the urine or of $\mathrm{N}$ retained, not the percentage of ingested $\mathrm{N}$ excreted in the urine or retained. Relationships between other metabolites, such as the ratios or levels of individual amino acids or groups of amino acids (cf. Leibholz, 1970) may prove more sensitive indices of the $\mathrm{N}$ status of the animal and the direction and rate of change of $\mathrm{N}$ status at a given time.

We are indebted to the Australian Wool Board and the Australian Meat Research Committee for the financial support of this project. One of us (R.C.K.) was supported on a Wool Board Postdoctoral Fellowship. The technical assistance of Mrs C. Spall, Miss J. Barker, Messrs J. P. Hantrais, S. Richardson and J. Maloney is gratefully acknowledged. We are also indebted to Mrs M. Atkinson for the statistical analysis.

\section{REFEREN CES}

Abou Akkada, A. R. \& Osman, H. El S. (1967). F. agric. Sci., Camb. 69, 25.

Allden, W. G. \& Jennings, A. C. (1969). Aust. F. agric. Res. 20, 125.

Chalmers, M. I. \& Synge, R. L. M. (1954). Adv. Protein Chem. 9, 23.

Cline, J. H., Hershberger, T. V. \& Bentley, O. G. (1958). F. Anim. Sci. r7, 284.

Conway, E. J. (1957). Microdiffusion Analysis and Volumetric Error 4th ed. London: Crosby Lockwood and Son.

el-Shazly, K. (1958). F. agric. Sci., Camb. 51, 149.

Fisher, L. J., Bunting, S. L. \& Rosenberg, L. E. (1963). Clin. Chem. 9, 573.

Ide, Y., Shimbayashi, K. \& Yonemura, T. (r967). Jap. F. zootech. Sci. 38, 1 1о.

Jasiorowski, H. (1960). Proc. int. Grassld Congr. virr. Reading p. 538.

Kellaway, R. C. (1969). Aust. F. exp. Agric. Anim. Husb. 9, 578.

Leibholz, J. (1970). Aust. F. agric. Res. 21, 723.

Lewis, D. (1957). Y. agric. Sci., Camb. 48, 438.

McDonald, I. W. (1952). Biochem. $\mathscr{~ 5 1 , ~} 86$.

McKenzie, H. A. \& Wallace, H. S. (1954). Aust. F. Chem. 7, 35.

Robertson, J. A. \& Hawke, J. C. (1965). F. Sci. Fd Agric. 16, 268.

Robinson, J. J. \& Forbes, T. J. (1967). Br. F. Nutr. 21, 879.

Tagari, H., Dror, Y., Ascarelli, I. \& Bondi, A. (r964). Br. F. Nutr. 18, 333.

Weston, R. H. \& Hogan, J. P. (I968). Proc. Aust. Soc. Anim. Prod. 7, 359. 